\title{
Mažujų valstybių veikimo būdai NATO ir ES bendroje saugumo ir gynybos politikoje
}

\begin{abstract}
Mažos valstybès yra svarbios tarptautinès bendruomenės narès. Jos nepriklauso galingiausių valstybių klubams, tačiau savo aktyvumu ir nuoseklia politika gali tapti svarbiomis veikejomis tarptautinejje arenoje. Šio straipsnio tikslas parodyti mažųjų valstybių veikimo būdus ir strategijas siekiant savo tikslų dviejose organizacijoje - NATO ir Europos Sąungoje. Straipsnyje pabrèžiama, kad mažosios NATO ir ES narès gali maksimizuoti savo galią aljansuose, jei laikosi kryptingos strategijos veikdamos ịvairiais lygiais. Mažos valstybès gali igyvendinti savo nacionalinius interesus, jei praktiškai prisideda prie tarptautinio saugumo stiprinimo, suburia kvalifikuotą personalą, kelia ir plètoja naujas iniciatyvas ar išnaudoja kitus savo privalumus. Straipsnyje pabrèžiama, kad mažujų valstybių ịtaka visada turès tam tikras natūralias ribas - kai jų veiksmai paliečia svarbius didžiųjų narių interesus, mažujų įtakos sklaida yra labai suvaržoma. Šiame straipsnyje parodomi mažujų valstybių veikimo būdai pateikiant mažųjų valstybių, ịskaitant Lietuvos, veiksmų pavyzdžių. Oro policija Baltijos šalyse yra puikus pavykusios mažų valstybių iniciatyvos pavyzdys, o bandymas prieš keletą metų peržiūrèti Europos saugumo strategiją baigèsi nesèkme. Norèdamos sèkmingai veikti mažosios valstybès visada turi nusistatyti aiškius prioritetus ir susitaikyti, kad nemažai jų iškeltų gerų iniciatyvų bus niekada neigyvendinta.
\end{abstract}

\section{Ivadas}

Europa yra mažų valstybių žemynas. Nors dažnas Lietuvos gyventojas guodžiasi, kad mes esame maža tauta ir nedaug ką sprendžiame tarptautiniame lygmenyje, tačiau praktika rodo, kad mažos šalys gali ir moka veikti tarptautinejje arenoje. Lietuva nèra išimtis, nors pagal gyventojų skaičių ji yra 35, o pagal teritoriją netgi 26 iš daugiau kaip penkiasdešimties Europos valstybių. Vis dèlto, pagal dažnai tarptautinių santykių analizei naudojamą mažųjų valstybių teoriją, Lietuva yra mažoji valstybė (angl. small state).

Viešame diskurse yra gana paplitusi nuomonè, kad mažosios NATO ir ES narès neturi balso. Dažnas Lietuvos gyventojas, besidomintis saugumu, su

\footnotetext{
* Dr. Vaidotas Urbelis - Lietuvos karo akademijos Politikos mokslų katedros dèstytojas. Adresas korespondencijai: Šilo 5a, 10332 Vilnius; tel. (8 5)210 3569; el. paštas: vaidurb@gmail.com.
} 
nemaža pašaipos doze komentuoja mūsų politikų pasisakymus apie nuveiktus darbus tarptautineje arenoje. Toks požiūris nèra teisingas. Mažosios valstybès gali turèti neproporcingai didelę įtaką tokiose organizacijose kaip NATO ir ES, jeigu aktyviai, nuosekliai dirba ir žino, ką nori pasiekti. Mažosios valstybės negali prilygti didžiosioms savo karine ar ekonomine galia, todèl nenorèdamos tapti tik pastarųjų valios vykdytojomis, turi veikti sumaniai, greitai ir energingai.

Mažųjų valstybių santykis su aljansais ar kitomis organizacijomis yra dažnas akademinio domėjimosi objektas. Dažnai nagrinèjama, kokia mažųjų valstybių motyvacija, kokios priežastys lemia jų prisijungimą prie vieno ar kito tarptautinio darinio. Akademinèje literatūroje dažnai galima aptikti mažų jųvalstybių elgesio modelių ar santykio su didžiosiomis valstybėmis tyrimus ${ }^{1}$. NATO ir ES tematiką nagrinejjančioje literatūroje labai aktualus yra naštos pasidalinimo klausimas, kurio aktualumas ypač padidejo po Šaltojo karo, kai Europa pradejjo labai mažinti išlaidas gynybai.

Šiame straipsnyje mažų valstybių veiksmai bus nagrinëjami kitu aspektu pagrindinis klausimas yra, kaip ir kokiu būdu mažos šalys gali maksimizuoti savo galią Aljanse ir kitose tarptautinėse organizacijose. Straipsnyje nebus gilinamasi, kodèl jos jungiasi prie aljansų, ar kaip veikia galios balansavimo mechanizmas tokioje sudètingoje sistemoje. I šiuos klausimus atsakyti yra parašyta gana daug knygų ir straipsnių. Šis straipsnis skirtas parodyti būdus, kaip realiame gyvenime mažosios valstybès veikia ir siekia savo tikslų, kokiais būdais gali ginti savo interesus.

Mažos šalys gali daryti ịtaką spendimams keliais būdais - neorealistai aiškintų, kad ịtaka jos daro pasinaudodamos santykine savo galia, ypač tais klausimais, kur turi gyvybinių interesų. Mažų šalių privalumas gali būti specifinė geografija, tam tikri resursai, palankios koalicijos. Neoliberalai teigtu, kad jos daro ịtaką remdamosios savo švelniąja galia ịtikinèjimams, apeliacijai ị bendras vertybes, kurios svarbios tokiose organizacijose kaip NATO ir ES². Šiame straipsnyje nèra ieškoma tiesioginio atsakymo, kuri teorija pateikia geresnị modelį aiškinant mažųjų valstybių elgesį. Šio straipsnio tikslas ne toks ambicingas - juo siekiama parodyti mažųjų valstybių veikimo būdus ir strategijas.

Šio straipsnio tyrimo objektas - mažųjų valstybių veikla NATO ir ES bendrosios saugumo ir gynybos politikos (BSGP) kontekste. NATO ir ES nèra

\footnotetext{
${ }^{1}$ Reiter E., Gärtner H., eds. Small States and Alliances, Physica, 2001, Keohane, R. O. "The Big Influence of Small Allies", Foreign Policy, 1971, 2, p.161-182, Hey J. A. K., ed., Small States in World Politics: Explaining Foreign Policy, Lynne Rienner Pub, 2003, arba bendresnio pobūdžio knygos, tokios kaip Walt S. M., The Origins of Alliances, Cornell University Press, 1997.

${ }^{2}$ Honkanen K., "The influence of small states on NATO decision making process (The membership experience of Denmark, Norway, Hungary and the Czech Republic)", FOI, 2002, p. 27-28.
} 
identiškos organizacijos, tačiau jas jungia keli bendri bruožai, kurie leidžia nagrinèti mažų šalių veiklą viename straipsnyje. Visų pirma, net 22 šalys priklauso abiem organizacijoms. Tiesa, Danija nedalyvauja karinèje BSGP dimensijoje, nors ir yra ES narè. Kita vertus, ne ES narè Norvegija gali prisijungti prie BSGP iniciatyvų, pavyzdžiui, kovinių grupių. Dauguma iš tų šalių yra būtent mažos šalys.

Antra, abiejose organizacijose svarbų vaidmenį vaidina ne tik valstybės, bet ir centrine biurokratija, kuri turi įtakos ruošiant sprendimus. Valstybės visada turi galutini žodị, bet NATO tarptautinio personalo ir ES Išorinių veiksmų tarnybos veikla, jų pagalba surandant konsensusą yra gana didelè. Trečia, abiejose organizacijose yra lyderis, kuris formuoja naujas iniciatyvas ir skatina eiti pirmyn. NATO toks vaidmuo tenka JAV, o ES - Prancūzijai. Ketvirta, tai demokratinių šalių klubai, kur pagarba kito interesams ir konsensuso paieška yra svarbios vertybès visoms šalims. Tai itin svarbus faktorius mažoms šalims.

Nereikia pamiršti ir akivaizdžių skirtumų. ES yra supranacionalinè organizacija, kurios interesų laukas yra labai didelis, o NATO užsiima tik saugumu. NATO neturi nieko panašaus ị Europos Komisiją ar ES teismą. Skiriasi ir sprendimų prièmimo būdas - NATO visi sprendimai priimami tik konsensusu, o ES kai kurie sprendimai priimami balsų dauguma. Kvalifikuotos daugumos balsavimas nèra dažnas BSGP srityje ${ }^{3}$, tačiau egzistuoja ir tam tikros išimtys, kurios svarbios, pavyzdžiui, analizuojant Europos gynybos agentūros veiklą. Toks metodas aiškiai mažina mažujų valstybių ittaką sprendimų prièmimui.

Nepaisant šių skirtumų, akivaizdūs panašumai leidžia manyti, kad mažujų valstybių elgesys abiejose organizacijose neturètų labai skirtis - panaudodamos savo turimos svertus, jos sieks, kad organizacijos leistu joms igyvendinti nacionalinius interesus ir daryti įtaką bendriems sprendimams, taip priversdamos didžiąsias šalis palaikyti jų poziciją.

Straipsnyje naudojama ta pati mažųjų valstybių apibrèžtis kaip ir prieš kelerius metus publikuotoje mano analizėje „Mažųjų valstybių reikšmé NATO išmaniosios gynybos iniciatyvose ".4 Straipsnyje kiekviena valstybè, kurios gynybos biudžetas yra mažiau kaip 10 mlrd. JAV dolerių, priskiriama mažųjų valstybių kategorijai. Tokia apibrèžtis tinka visoms NATO ir ES valstybèms, išskyrus JAV, Didžiąją Britaniją, Prancūziją, Vokietiją, Italiją, Kanadą, Turkiją, Ispaniją ir Olandiją. 2015 metais šią ribą peržengè ir Lenkija. Šis sąrašas beveik identiškas R. De Wijk paskelbtoje studijoje, kurioje vertinamas NATO šalių

\footnotetext{
${ }^{3}$ Pavyzdžiui, sprendimai dèl nuolatinio struktūrinio bendradarbiavimo ar Europos gynybos agentūros vadovo priimami kvalifikuotos daugumos balsavimu.

${ }^{4}$ Urbelis V. „Išmaniosios gynybos pasekmès mažosioms Aljanso narèms“, Lietuvos metinè strategine apžvalga, 2012-2013, t. 11, p. 9-29.
} 
karinis pajègumas ${ }^{5}$, sąrašui. R. De Wijk aiškiai pabrèžia, kad mažųjų valstybių išskirtinis bruožas - nesugebejimas turèti viso karinių pajègumų spektro ir negalejimas savarankiškai panaudoti karinių instrumentų kitose pasaulio dalyse. Karinio mažujų valstybių veikimo laisve yra labai apribota didžiųų valstybių, jos priklausomos nuo didžiųjų šalių karinių pajègumų, o jų saugumo garantas yra kolektyvinès gynybos susitarimai.

Danija yra geriausias mažos, tačiau aktyvios ir įtakingos NATO šalies pavyzdys. Vien tai, kad ankstesnis NATO generalinis sekretorius ir Karinio komiteto pirmininkas buvo danai, parodo, kad šios šalies atstovai yra labai gerbiami. Danija yra viena aktyviausių NATO šalių pagal iniciatyvų skaičių, ji aktyviai dalyvauja tarptautinèse operacijose, plètoja paramos politiką, yra aktyvi Baltijos jūros ir Šiaurès Europos regione. Baltijos šalys savo karinius vienetus yra priskyrusios Danijos divizijai, o jos instruktoriai buvo itin svarbūs kuriant Lietuvos, Latvijos ir Estijos kariuomenes ${ }^{6}$.

Daug kas nustebs sužinoję, kad Šaltojo karo metu Danijos užsienio politika išgyveno vadinamąją , ,išnašų erą“ - tokị pavadinimą ji pelnè todèl, kad prieštaraudavo daugumai NATO sprendimų, ypač branduolinio ginklo klausimais ${ }^{7}$. Tačiau pasibaigus Šaltajam karui, Danija pasikeitè - dèl savo aktyvumo per vieną dešimtmetị iš vidutiniokès tapo viena iš NATO šalių lyderių. Kai kyla diskusijos dèl NATO ateities, dèl operacijos Afganistane ar NATO pratybų, daugumai valstybių Danijos nuomonè yra itin svarbi. Šis pavyzdys puikiai ịrodo, kad ne valstybès dydis viską lemia. Mažosios valstybès ne tik nèra klusnios didžiųjų tarnaites, bet ir pačios stengiasi didžiąsias palenkti sau naudinga linkme. Jos turi savo nuomonę ir ją aktyviai gina.

Tiesa, yra ribos - mažosios niekada nebus tokios ịtakingos kaip didžiosios valstybès, bet norèdamos jos gali pasiekti daug daugiau, negu galima būtų tikètis tik pagal valstybès dydị. Mažų šalių ịtaką šiame straipsnyje nagrinėsime pagal du pagrindinius veiksnius: pirma, kaip ji sugeba daryti įtaką organizacijos darbotvarkei, iškelti probleminius klausimus ir priversti diskutuoti, antra, sugeba daryti įtaką sprendimams klausimų, kurie jau yra darbotvarkejje, ir ịtikinti, kad jie yra svarbūs ir būtini igyvendinti. Tai leis detaliau išnagrinèti mažų šalių veikimo būdus NATO ir ES viduje.

\footnotetext{
${ }^{5}$ De Wijk R. "Security Implications of NATO Transformation for Smaller Members" in Setälä M., ed., Small States and NATO, Atlantic Council of Finland, 2005, p. 17-23.

${ }^{6}$ Wammen N. "Close allies and friends - Ten years on" in Vestenskov D., ed., 10 Years after NATO membership - an anniversary in the shadow of a crisis, Royal Danish Defence Institute, p. 12.

7 "Small States in NATO: Influence and Accommodation. A thematic summary of the panel discussion" in Setälä M., ed., Small States and NATO, Atlantic Council of Finland, 2005, p. 27-28.

${ }^{8}$ Honkanen K., Op. cit., p. 16.
} 


\section{Solidarumas ir konsensuso principo svarba}

NATO ir ES narès yra vieno klubo narès - jos turi rūpintis viena kitos saugumu ir bendra gerove. Šiaurès Atlanto sutarties 5-asis straipsnis ịpareigoja jas viena kitą ginti ginklu, jei kuri nors būtų užpulta priešininko. Nieko nèra stipresnio už ịsipareigojimą aukoti savo žmonių gyvybes bendrų interesų labui. Tai nereiškia, kad visais klausimais NATO narès yra bendramintės. Irako karo metu jos buvo rimtai susipykusios, tačiau tai niekaip nepaveike jų įsipareigojimų viena kitai. Valstybès dydis tokiais atvejais nèra svarbus, mažos ir didelès šalys bus ginamos vienodai. ES šalis sieja kiek silpnesnè, nors taip pat svarbi Lisabonos sutartyje ịrašyta Solidarumo sąlyga, kuri skelbia, kad „Sąjunga ir valstybès narès veikia bendrai ir solidariai, jei kuri nors valstybè nare patirtų teroro aktą, gaivalinę nelaimę ar žmogaus sukeltą katastrofą. "

Solidarumas ir bendros vertybès sudaro bendrą NATO ir ES, kaip demokratinių šalių klubo, pagrindą. Tai savotiška bendruomenė, jos žmonès yra susiję tarpusavio pagarba ir supratimu. Mažosios valstybės yra šios bendruomenès narès, o demokratinèje visuomenejje visų nuomonè turi būti išklausyta. Priklausymas demokratinių valstybių sąjungai visas šalis (dideles ir mažas) ipareigoja elgtis atitinkamai, atsižvelgti į viena kitos interesus. Šią NATO ir ES savybę mažosios narès puikiai išnaudoja ${ }^{10}$.

Mažųjų šalių dalyvavimas leidžia didžiosioms atsikratyti stereotipo, kad tik keletas didžiųjų valstybių valdo pasaulį. İvairaus dydžio šalių koalicijos legitimizuoja didžiųjų valstybių veiklą, daro jų priimamus sprendimus priimtinesnius pasaulio bendruomenei. NATO operacijai Libijoje $2011 \mathrm{~m}$. labai reikèjo tokių Aljanso narių kaip Bulgarija, Danija, Graikija, Rumunija dalyvavimo, taip pat partnerių iš Jordanijos, Kataro, Švedijos ar Jungtinių Arabų Emyratų paramos. Prancūzija savo veiksmams Afrikoje beveik visada bando sutelkti tarptautinę paramą - tai labai svarbu politikams ir gyventojams.

Reiktų atskirai pažymèti JAV elgesị kitų NATO šalių atžvilgiu. NATO viduje JAV elgesys labiau atitinka „sąžiningojo arbitro“, o ne „valdingojo diktatoriaus" principus, o mažujų valstybių parama yra svarbi legitimizuojant JAV lyderystę. Tik išskirtiniais atvejais amerikiečiai bando primesti kitoms šalims savo valią. Amerikiečių lyderystė yra grịsta ne tiek jų turima jèga, bet bandymu ịsiklausyti $\mathfrak{i}$ kitų šalių problemas ir suderinti ịvairius interesus. Tai puiki galimybè mažoms šalims paveikti ir argumentais palenkti stipriausią Aljanso

\footnotetext{
${ }^{9}$ Lisabonos sutartis, https://www.ecb.europa.eu/ecb/legal/pdf/lt_lisbon_treaty.pdf.

${ }^{10}$ Solidarumo reikšmė buvo aiški nuo pat NATO įkūrimo pradžios, žr. Spinelli A., "Atlantic Pact or European Unity”, Foreign Affairs, 1962, 40 (2), p. 542-552.
} 
valstybę sau naudinga linkme. ES viduje situacija dar paprastesnè - dvi didžiausios karinès Europos galybès Prancūzija ir Didžioji Britanija, siekdamos sau parankių sprendimų, visada ieško mažesnių šalių paramos, todèl jų itaką dar labiau išauga.

Kiekvienas didžiujų bandymas įvesti „savo tvarką“ NATO ir ES baigdavosi nesèkme. Kai 2003 m. pradžioje Vokietija ir Prancūzija pasiūlè paskirti stiprų Europos valstybių vadovų tarybos pirmininką, kuris turètų didelius igliojimus užsienio praktikoje, mažosios valstybès sunerimo, kad tai įtvirtins didžiųjų šalių dominavimą. Todèl sprendimas buvo blokuotas ir pavadintas mèginimu sukelti „konstitucinị perversmą“ arba sukurti „sisteminę oligarchiją “" Mažujų valstybių požiūris į ES institucijų reformą buvo aiškus - valstybių narių lygybè yra esminis principas, kurio privalu laikytis reformuojant Sajungos institucijas. 1958 m. Prancūzijos prezidentas pasiūle JAV ir Didžiajai Britanijai sukurti trijų šalių direktoratą NATO viduje, kuriame būtų priimami svarbiausi sprendimai dèl karinio planavimo ir karinių veiksmų vykdymo. ${ }^{12}$ Nesunku atspeti, kad tokia iniciatyva susilaukè mažesnių šalių (ir JAV) pasipriešinimo ir greitai žlugo ${ }^{13}$.

Formaliai žiūrint, viena pagrindinių mažujų valstybių įtakos paaiškinimų yra konsensuso taisyklè. Nors ir buvo bandymų šią taisyklę pakeisti, NATO viduje mažosios šalys tam pasipriešino. ES BSGP konsensuso paieška taip pat yra pagrindinè sprendimų prièmimo forma. Taigi, abiejose organizacijose kiekviena šalis gali pakelti ranką (dažniausiai - parašytą raštą), ir sprendimas nebus priimtas. Nesvarbu, ar tai maža, ar didelè valstybė, kiekviena turi teisę pasakyti „ne“.

Skeptikai pasakys, kad tai visiška netvarka, nes suderinti 28 valstybių interesus yra neįmanoma. Iš tiesų, valstybių interesus suderinti labai sunku, jų norai dažnai skiriasi. Visiems tenka nusileisti, atsižvelgti ị kitų interesus. NATO ir ES komitetuose sklando posakis: „Jeigu visi išliko nepatenkinti, vadinasi, kompromisas buvo geras“. Tai darbo kultūros, kai išmokstama gerbti kitų nuomonę ir rasti bendrą sprendimą, rezultatas. Todèl konsensuso taisyklè nedaro tokios didelès žalos, kaip gali atrodyti iš pirmo žvilgsnio. Tokiu būdu priimti sprendimus yra sunkiau, tačiau kai jie būna priimti, tada niekas nebegali jų užginčyti. Jeigu sprendimas priimtas, tai visi privalo jo laikytis. Jeigu dokumentas pasirašytas, jo teiginiai kartosis ir kituose. Pavyzdžiui, sutartas tekstas dèl NATO vaidmens energetinio saugumo srityje. NATO strategineje koncepcijoje aiškiai pasakyta, kad NATO turi „kurti pajègumus, prisidedančius prie energetinio saugumo, ịskaitant kritinès infrastruktūros ir tranzitinių

\footnotetext{
${ }^{11}$ „Tyranny of the Tiny“, The Economist, 366 (8308), 23 January 2003.

${ }^{12}$ Honkanen K. Op. cit., p. 40.

${ }^{13}$ Pagedas C. A., Anglo-American Strategic Relations and the French Problem, 1960-1963: A Troubled Partnership, Frank Cass, 2000, p. 30-34.
} 
kelių apsaugą <...>“.14 Taigi kiekvienas, kuris kituose dokumentuose siūlytų parašyti, kad NATO neturi vaidmens energetinio saugumo srityje, būtu greitai nutildytas. Ir atvirkščiai - nuomoné, kad NATO turi užtikrinti dujų ar naftos tiekimą Aljanso narèms, lygiai taip pat būtų greitai paneigta.

Rèmimasis tokia „rašytine teise“, kurios pagrindas yra ịvairūs NATO ir ES sutarti dokumentai, leidžia mažosioms valstybèms blokuoti joms nepriimtinus sprendimus ar tartis dèl tam tikrų nuolaidų: „Jeigu jūs nusileisite dèl punkto A, tai mes nusileisime dèl B.“ Dar daugiau - maža šalis gali užblokuoti kokị nors jai visiškai nesvarbų klausimą, tikẻdamasi „iškeisti“ jị i kitą jai svarbų tekstą kitur. Todèl nieko nestebina, kai svarbių susitikimų metu netikètai priešraketinès gynybos klausimas tampa susijęs su operacijų finansavimo klausimu, nors tiesioginio ryšio tarp jų kaip ir nèra. Toks savotiškas turgus ir skirtingų klausimų susiejimas leidžia mažosioms valstybèms pakreipti NATO ir ES politiką viena ar kita joms reikiama kryptimi.

Vidinès organizacijos kultūros ir konsensuso principo taikymo negalima suabsoliutinti. Mažosios valstybès neblokuoja sprendimų bet kada to panorejusios. Dauguma jų supranta, kad prieštaraudamos bet kam, kas joms nepatinka, pakenks savo reputacijai ir pačiai organizacijai. Pavyzdžiui, iprasta, kad maža šalis, nedalyvaujanti kokioje nors NATO operacijoje, ta tema susitikimuose iš viso nekalba. Valstybès, neturinčios laivyno, beveik niekada nedalyvauja diskusijose apie NATO jūrų strategiją, o šalys, neturinčios interesų Europos Šiaurèje, retai diskutuoja Arkties klausimais. Kiekviena maža šalis jaučia ribas, kurias peržengus jos autoritetui grèstų pavojus.

\section{Aktyvumas ir nacionalinių interesų kèlimas}

Aktyvi užsienio ir saugumo politika yra vienas svarbiausių mažųjų valstybių svertų. Dauguma mažųjų narių yra itin aktyvios tarptautinėse operacijose. NATO vadovaujamoje operacijoje Afganistane Estijos, Norvegijos ir Danijos aukų skaičius palyginti su šių šalių gyventojų skaičiumi buvo neproporcingai didelis ${ }^{15}$, o tokios šalys, kaip Lietuva, Vengrija, savarankiškai vadovavo provincijos atkūrimo grupèms. Lenkija $2003 \mathrm{~m}$. Irake vadovavo vienam iš keturių okupacinių sektorių, o štai Norvegija ir Belgija buvo vienos aktyviausių

\footnotetext{
${ }^{14}$ NATO's role in energy security, http://www.nato.int/cps/en/natolive/topics_49208.htm.

${ }^{15}$ Jakobsen P. V., Ringsmose J. "For our own security and for the sake of the Afghans. How the Danish public was persuaded to support an unprecedented costly military endeavor in Afghanistan" in de Graaf B., Dimitru G., eds., Strategic Narratives, Public Opinion and War Winning domestic support for the Afghan War, Routledge, 2015, p. 118-140.
} 
operacijos Libijoje dalyvių, kiekviena skirdama po šešis F-16 naikintuvus ir papildomą personalą. Mažosios valstybès aktyvios ir ES operacijose Malyje, Somalyje, Konge. Toks aktyvumas verčia didžiąsias šalis gerai įsiklausyti ị mažųjų nuomonę sprendžiant ir kitus, nebūtinai su šia operacija susijusius klausimus.

Aišku, mažosios šalys neturètų persistengti pabrèždamos kokị nors klausimą, kuriam pagrịsti nèra pakankamai argumentų. Toks bandymas gali būti tiesiog kontrproduktyvus ir kelti didžiụjų šalių susierzinimą, ar netgi sukelti kitų svarbių klausimų blokavimą. Aktyvumas turi tureti prasmę ir aiškų tikslą (ko norima pasiekti). Aktyviai veikiant, turi būti žinoma kaip kolektyvinès gynybos organizacija gali atsakyti ị vieną ar kitą klausimą.

Aktyvumas svarbus ne tik dalyvaujant organizacijų veikloje, bet ir pabrěžiant problemas, keliant klausimus ar inicijuojant diskusiją. Tai priverčia didžiąsias šalis kalbetti, diskutuoti ir turèti aiškią poziciją mažoms šalims rūpimais klausimais. Kartais tai būna didžiosioms šalims nemalonūs klausimai, kuriais jos net nenorètų diskutuoti, tačiau būna priverstos tai daryti, kai atkakli mažoji valstybė apie tai pradeda kalbèti viešai ar uždarų susitikimų metu. $2008 \mathrm{~m}$. Lietuva ir Lenkija tokiu būdu privertè ịtraukti energetinio saugumo klausimą j NATO viršūnių susitikimo Bukarešte darbotvarkę. Lengviausia tokiose diskusijoje yra priimti sprendimą daugeliui šalių nelabai svarbiu ir nekontraversišku klausimu, kuris nepažeidžia kitų interesų. Kitu atveju, sèkmės tikimybė sumažèja iki minimumo.

Puikus tokio veikimo pavyzdys yra Lietuvos ir Danijos inicijuotas NATO žaliosios gynybos projektas. Šios iniciatyvos priežastis - NATO šalių kariuomenès suvartoja daug energijos. Mažèjant gynybos biudžetams, gebejimas taupyti pinigus diegiant ekologiškas technologijas būtų puikus išmaniosios gynybos pavyzdys. Afganistanas patvirtino, kad energijos resursu taupymas yra svarbus operacinès sèkmès elementas - vienam litrui degalų $\mathfrak{i}$ Afganistaną nugabenti reikèdavo sunaudoti 7 litrus degalų ${ }^{16} .2013$ metais Lietuvos ir Danijos gynybos ministrai kreipèsi ị savo kolegas siūlydami kartu dirbti kuriant inovacijas ir skatinti efektyvesnị išteklių naudojimą. NATO energetinio saugumo kompetencijos centras tapo svarbia šios iniciatyvos dalimi. Nors nemažai NATO šalių netapo didžiuliais šios iniciatyvos šalininkais, bet tiesiog nebuvo argumentų blokuoti tokią gerą idèją. Žalioji gynyba tapo NATO darbotvarkès dalimi, tai atsispindejjo ir NATO Velso viršūnių susitikimo deklaracijoje ${ }^{17}$.

\footnotetext{
${ }^{16}$ Denmark and Lithuania promote Green Energy and Defence Initiative at NATO Ministerial, http:// nato.mfa.lt/nato/en/news/denmark-and-lithuania-promote-greenenergy-and-defence-initiative-at-natoministerial.

${ }^{17}$ NATO, Wales Summit declaration, http://www.nato.int/cps/en/natohq/official_texts_112964.htm.
} 
Kitas mažujų valstybių veikimo pavyzdys yra Balkanai. Dauguma mažų regiono valstybių, bijodamos situacijos Bosnijoje ir Hercegovinoje ar Kosove eskalavimo, nuolat NATO ir ES forumuose pabrèžia, kad tarptautinè bendruomenè turi išlaikyti karines pajègas šiame regione. Jų pateikiama informacija, ittikinejjimas ir pačių nuveikti darbai lemia, kad NATO ir ES iki šiol išlieka esminiai saugumo veikejjai regione. Nepaisant vyraujančio spaudimo gerokai sumažinti pajėgų skaičių regione, NATO operacija Kosove (KFOR) ir ES operacija Bosnijoje ir Hercegovinoje tęsiasi iki šiol.

NATO plètrą taip pat galima vertinti kaip mažųų valstybių sugebejimo daryti įtaką politiniams sprendimams rezultatą. Būtent Danijos, Lenkijos ir kitų šalių nuolatinis darbas ir ịtikinejjimas prisidejo prie to, kad prieš dešimt metų Lietuva kartu su kitomis šalimis tapo NATO narèmis. Aišku, mažosios šalys nedaug būtų nuveikusios, jeigu ne reikiamu momentu parodyta JAV lyderysté, bet jos puikiai paruošè dirvą vèliau priimtiems sprendimams. 2014 metais panašiai galèjo atsitikti ir vykstant debatams dèl Juodkalnijos narystès NATO. Būtent dvi mažosios valstybès - Slovėnija ir Kroatija sukèlè debatus dèl Juodkalnijos pakvietimo. Abu šie atvejai puikiai parodo ir mažujų valstybių ittakos ribas - jei ne JAV parama, Baltijos šalys nebūtų tapusios NATO narèmis. Slovenija ir Kroatija daug nuveikè, kad Juodkalnija irgi būtų pakviesta, bet 2014 m. NATO viršūnių susitikimo metu Juodkalnija kvietimo prisijungti prie NATO negavo.

Kitas puikus pavyzdys - oro policija. Lietuva ir kitos Baltijos šalys aktyviai sieké, kad oro policija taptų ilgalaike NATO misija, o ne būtų reguliariai persvarstoma kaip buvo iki 2012 metų. Pradejjus pokalbius šia tema su didžiosiomis NATO valstybėmis, Baltijos šalys susidūrè su nemažu skepticizmu niekas nenorèjo ịsipareigoti tokiai misijai ilgam laikotarpiui, kai kurios šalys netgi kvestionavo patị oro policijos poreikị. Siekdamos ịtikinti skeptikus, Baltijos šalys nutare parengti studiją, kur būtų išnagrinètos ịvairios oro policijos atlikimo galimybès, ịskaitant naikintuvų ịsigijimą. Tokios studijos tikslas buvo paprastas - pateikti visus argumentus, suskaičiuoti pajègu poreikị, Baltijos šalių galimybes ir svarbiausia - parodyti, kiek kainuos ịvairių sprendimų igyvendinimas.

Studijos išvados nieko nenustebino - oro policiją efektyviausia vykdyti kitoms NATO šalims dislokuojant mažiausiai keturis naikintuvus Baltijos šalyse. Pabaigta studija buvo pristatyta NATO šalims tiek Briuselyje, tiek šalių, dalyvaujančių misijose, sostinėse. Baltijos šalys taip pat išplatino klausimynus, kur naikintuvus turinčios valstybès galëjo reikšti ịvairius pageidavimus dèl priimančios šalies paramos ir jų naikintuvų, dislokuotų Baltijos šalyse, priežiūros. 
Paaiškejjo, kad NATO valstybėms rūpi du pagrindiniai dalykai - finansavimo ir treniročių sąlygos. Po truputị šie klausimai buvo išspręsti prieš NATO viršūnių susitikimą sutarus dèl naujo priimančios šalies paketo. Jame išvardyti Baltijos šalių įsipareigojimai. Pirma, Baltijos šalys ịsipareigoja prisidèti prie misijos vykdymo finansiškai skirdamos $5 \mathrm{mln}$. eurų per metus ${ }^{18}$. Tai vidutinè suma, kurią šalys papildomai išleidžia vykdydamos oro policijos misiją. Antra, jos turi modernizuoti savo poligonus, kuriuos galima panaudoti lèktuvų treniruotėms, gerinti skraidymo sąlygas, kad pilotai neprarastų savo ịgūdžių ir galètų kelti kvalifikaciją.

Studijos parengimas ir naujas priimančios šalies paketas nuginčijo skeptikų argumentus dèl ilgalaikio sprendimo veiksmingumo. Remiamos JAV ir Danijos, Baltijos šalys po truputi $\mathfrak{x}$ savo pusę patrauke daugelį kitų NATO šalių. Rezultatas - Čikagos viršūnių susitikimo sprendimas, kad „NATO sveikina sprendimą tęsti oro policijos misiją Baltijos šalyse ir pritaria Baltijos šalių sprendimui skirti papildomą priimančios šalies paramą dalyvaujančioms vals-

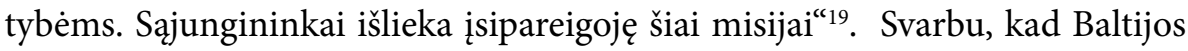
šalių pasiūlytos sąlygos buvo pritaikytos ir Rusijos agresijos Ukrainoje metu atsiųstam NATO oro policijos pastiprinimui.

Veikiant tokiu būdu viena svarbiausių mažujų valstybių sẻkmès taisyklių - aiškus prioritetų nustatymas. Mažos valstybės stengiasi ginti tik tuos interesus, kurie joms yra gyvybiškai svarbūs. Anksčiau minèta NATO plètra ar oro policija yra puikus tokio veikimo pavyzdys. Veikdamos tokiose sudètingose organizacijos kaip ES ir NATO, jos turi labai aiškiai nusistatyti prioritetus ir jiems skirti didžiausią dèmesị. Šalių prioritetai - istorijos, geografijos ir saugumo situacijos pasekmè. Pavyzdžiui, Turkija dažnai taiso dokumentus, kur kalbama apie Artimujų Rytų problemas, Norvegija ir Kanada - apie Europos Šiaurę, Baltijos šalys ir Lenkija - apie Europos rytines kaimynes, Rumunija ir Bulgarija - apie Juodosios jūros regioną, Prancūzija ar Didžioji Britanija - apie Afrikos šalis ir t. t.

Ne mažiau svarbi mažujų valstybių veiklos sritis yra mėgstamų ir propaguojamų temų pasirinkimas. Dauguma mažujų valstybių dèl istorinių ar kultūrinių priežasčių turi temų, kuriose jos specializuojasi ir siūlo ịvairių idejų̧. Pavyzdžiui, estai mėgsta kalbèti kibernetinès gynybos tema, lietuviai - apie energetini saugumą, danai - apie ekologiją, klimato kaitą, latviai - apie strateginę komunikaciją ir pan. Tose srityse, kuriose turi didelius interesus ir patirti, mažosios valstybės taip pat gali vaidinti svarbų vaidmenị. Geras pavyzdys yra

\footnotetext{
${ }^{18}$ BNS, NATO chief announces extension of Baltic air-policing mission without dates but with possibility of review, 21 May 2012.

${ }^{19}$ NATO, Chicago Summit declaration. http://www.nato.int/cps/en/natolive/official_texts_87593.htm.
} 
Čekija, kuri nuo senų laikų daug dėmesio skiria kovos su cheminiu ir biologiniu ginklu pajėgumams. Čekai turi gerus ekspertus, laboratorijas, kitą įrangą ir bando pirmauti šioje srityje, o nei viena diskusija apie specialiųju pajègu vaidmenį neapsieina be aktyvaus Lietuvos dalyvavimo ${ }^{20}$. Šiaurès šalys yra svarbios diskutuojant humanitarinès pagalbos klausimais, nes jų metinè parama yra vertinama apie $15 \mathrm{mlrd}$. dolerių per metus. ${ }^{21}$

NATO kompetencijos centrų kūrimas - svarbi tokios politikos dalis. Kibernetinès gynybos (Estijoje), Energetinio saugumo (Lietuvoje), Apsaugos nuo improvizuotųjų sprogdinimo užtaisų (Slovakijoje), Žmogiškosios žvalgybos (Rumunijoje), Apsaugos nuo cheminio, biologinio, radiacinio ir branduolinio ginklo (Čekijoje), Medicinos (Vengrijoje), Jūrinių minų (Belgijoje) kompetencijos centrai yra puikūs valstybių specializacijos pavyzdžiai, leidžiantys nukreipti mažų valstybių energiją tam tikra visiems naudinga linkme ${ }^{22}$. Tokiais atvejais mažos valstybès imasi savotiško lyderio vaidmens, skiria tai temai daugiau dèmesio ir kelia ịvairias jų interesus atitinkančias iniciatyvas. Tokio reiškinio pasekmé - didžiosios šalys beveik niekada nesiima svarbesnių veiksmų, nepasikonsultavusios su toje srityje aktyviausia mažąja valstybe.

Toks aiškių temų ir regionų išskyrimas leidžia mažosioms valstybẻms tapti savotiškomis tų sričių ekspertèmis, o prioritetų nustatymas - nukreipti pastangas konkretiems tikslams pasiekti. Tokia taktika dažniausiai pasiteisina. Pavyzdžiui, prieš NATO viršūnių susitikimą Lietuva nusibrežè tris aiškius konkrečius tikslus: kad būtų priimtas sprendimas dèl nuolatinès oro policijos, pripažintas NATO energetinio saugumo centras ir patvirtintos priemonès gynybos planams igyvendinti. Visus juos pavyko pasiekti ir paminèti valstybių vadovų priimtuose dokumentuose.

\section{Komitetai - vieta, kur gimsta sprendimai}

Kita svarbi mažųjų šalių įtakos priemonė yra darbas NATO ir ES komitetuose. Svarbiausi sprendimai NATO ir ES neatsiranda iš niekur, sèkmé dažniausiai yra ilgo darbo komitetuose, kurie ruošia valstybių vadovų ir ministrų susitikimus, rezultatas. Komitetai yra pagrindinis politinių sprendimų priemimų ịrankis, savotiškas filtras, kuriuo grūdai atsijojami nuo pelų.

\footnotetext{
${ }^{20}$ Laajava J., Burnes N., "Small States and NATO Facing the Contemporary Security Environment" in Setälä M., ed., Small States and NATO, Atlantic Council of Finland, 2005, p. 14.

${ }^{21}$ Brattberg E., "U.S.-Nordic Global Security Cooperation" in Advancing U.S.-Nordic-Baltic Security Cooperation, Center for Transatlantic Relations, p. 127.

${ }^{22}$ Centres of Excellence, NATO, http://www.nato.int/cps/en/natolive/topics_68372.htm.
} 
Komitetuose valstybės yra atstovaujamos vidutinès grandies pareigūnų, kurių pastangos yra esminès siekiant rezultatų aukštesniu lygmeniu. Čia glūdi viena pagrindinių mažųjų valstybių stiprybių. Komitetuose svarbu, ne tik iš kurios šalies tu esi, bet ir tavo asmeninès savybès ir sugebejjimas koordinuoti veiksmus su kitomis institucijomis. Mažos valstybės atstovui NATO ir ES komitete dažnai tereikia keleto telefono skambučiu ar elektroninio laiško, kad suderintų poziciją su „sostine“, t. y. pagrindinėmis klausimą kuruojančiomis institucijomis. O didelei valstybei suformuluoti poziciją dažnai reiškia ilgą derinimo tarp ịvairių institucijų (prezidentūros, premjero tarnybos, užsienio reikalų, gynybos ministerijų) procesą.

Todèl mažųuj valstybių atstovams daug paprasčiau būti lankstiems ir aktyviems nei jų kolegoms iš didžiųjų valstybių. Jie gali efektyviau dirbti, nes jų ryšiai ir kontaktai yra daug glaudesni. Viena yra dirbti Lietuvos Respublikos krašto apsaugos ministerijoje su trimis šimtais darbuotojų, visai kas kita Pentagone su 30 tūkstančių darbuotojų, kuriame pažịsti tik mažą dalị žmonių. Maža ir mobili struktūra, kur žmonės gerai vieni kitus pažịsta, yra didžiulis mažųjų valstybių privalumas.

Kitas mažųų valstybių veikos bruožas - tai aljansų ir koalicijų Aljanso viduje formavimas. Suprasdamos, kad pavieniui pasiekti rezultatų greitai neimanoma, jos linkusios veikti kartu ${ }^{23}$. Geras pavyzdys būtų prieš keletą metų gimusi iniciatyva didinti NATO matomumą Aljanso šalyse. Ši darbą pradejjo norvegai, parašę tris puslapius pasiūlymų, kaip galima išmaniai, panaudojant pratybas, gynybos planus, mokymą ir kitą veiklą, užtikrinti, kad būtų matomi NATO veiksmai net tik Afganistane, bet ir NATO šalyse saugant jų teritoriją. Greitai prie šios iniciatyvos prisidejo Lietuva, parengusi savo pasiūlymus, ją parèmé Latvija ir Estija. Galiausiai ir Čekija nusprende prisidèti. Didžiosios valstybès iš pradžių gana skeptiškai prièmé šias iniciatyvas, teigdamos, kad NATO ir taip gerai matoma. Tačiau po truputị mažosioms valstybems pavyko įtikinti didžiąsias valstybes, kad NATO matomumas yra visų šalių interesas. Tai, ką matome šiandien mūsų regione (pratybas, ̣̂vairius karinius renginius), yra iš dalies sèkmingos Lietuvos ir jos bendraminčių veiklos rezultatas.

Dirbant NATO ir ES, ne mažiau svarbu yra žmonių išsilavinimas ir darbo igūdžiai. Tikrai negalima teigti, kad mažujų valstybių piliečiai yra kuo nors geresni ar protingesni už savo kolegas iš didžiųjų valstybių. Taip nẻra ir negali būti. Tačiau paprastai mažujų valstybių atstovai geriau jaučiasi tarptautinejje terpejje. Tarptautiniai santykiai jiems yra gyvenimo būdas, jie ịpratę dirbti su užsieniečiais, yra mobilūs ir moka užsienio kalbų.

${ }^{23}$ Setälä M., ed., Small States in NATO, p. 27. 
Gera komunikacija prasideda nuo užsienio kalbų mokejimo. Pavyzdžiui, geros anglų žinios ir gebejiimas gerai kalbèti viešumoje yra didžiulis britų pranašumas, nedaug atsilieka ir Skandinavijos valstybè ${ }^{24}$. Neatsitiktinai NATO tarptautiniame štabe ar Europos išorinių veiksmų taryboje galima rasti neproporcingai daug Šiaurès Europos šalių atstovų, jie lengviau laimi konkursus ị svarbias pozicijas, o per tai galimybę daryti ịtaką priimant svarbius NATO ir ES sprendimus. ES svarbu yra ne tik anglų, bet ir prancūzų kalbos žinios, čia daugiau pranašumų turi pietinès ES šalys. Kalbos, iškalbos ir komunikacijų svarba išryškejja ruošiant svarbius dokumentus, deklaracijas, pareiškimus. Tokiose situacijose didžiulių privalumų turi anglosaksai ir skandinavai. Aišku, tokie debatai ar diskusijų meno sugebejimai labiau lemia tam tikrus NATO ar ES politikos niuansus, o ne esminius sprendimus. Kai ateina tikrų sprendimų metas, NATO ir ES lyderiai kalba tiesiai, be užuolankų.

\section{Mažos šalies pirmininkavimas ES Tarybai - Lietuvos pavyzdys}

Pirmininkavimas ES Tarybai buvo išskirtinis iššūkis Lietuvos valstybei. Daugybė susitikimų, parengtų dokumentų, moderuotų diskusijų - tai nemažas Lietuvos pasiekimas antraji $2013 \mathrm{~m}$. pusmetị. Idomu tai, kad po Lisabonos sutarties pirmininkaujančios šalies reikšmė BSGP sumažèjo. Lisabonos sutartimi buvo ịkurta nauja pareigybè - Sąjungos vyriausiasis igaliotinis užsienio reikalams ir saugumo politikai, kuris tuo pat metu yra ir Europos Komisijos vadovo pavaduotojas. Lisabonos sutartis iš dalies apibrěžia vyriausios igaliotinès pareigas, tačiau santykis su pirmininkaujančia šalimi nèra aiškiai apibrèžtas ${ }^{25}$. Akivaizdu, kad nuomonių spektras labai didelis - pradedant nuo to, kad BSGP sričiai pirmininkaujančios šalies nèra, o visas funkcijas atlieka vyriausioji igaliotinè (dažna centrinèse ES institucijose dirbančio personalo nuomonè), tačiau su nuostata, kad valstybès valdo procesą, o pirmininkaujanti šalis turi galimybę daryti ịtaką diskusijai ir galimiems sprendimams (dažna valstybių, ypač pirmininkaujančių, pozicija).

Neatsitiktinai, mažosioms valstybèms pirmininkaujant ES Tarybai, didžiosios šalys matė jas kaip atsvarą vis didejjančiam vyriausiojo igaliotinio do-

\footnotetext{
${ }^{24}$ Setälä M., ed., Small States in NATO, p. 25. Daugiau apie kalbų paplitimą Europos šalyse žr. European Commission, "Europeans and their languages", Special Eurobarometer 386, 2012.

${ }^{25}$ Helvik N., “The High Representative 3.0”, Briefing Paper 155, Finish Institute of International Relations, 2014, p. 3-4.
} 
minavimui rengiant sprendimus ir ieškant konsensuso. Šis veiksnys buvo itin svarbus ir tuo, kad gynybos klausimai 2013 metų pabaigoje buvo diskutuojami ir valstybių vadovų lygiu. Konkretūs pavyzdžiai puikiai iliustruoja Lietuvos veiklą.

\subsection{Rytụ partnerystès}

Rytu partnerystés buvo bendras Lietuvos pirmininkavimo prioritetas, todèl jis turejo atsispindèti ir BSGP dalyje. Pasirengimas išplèsti šią ES dimensiją prasidèjo dar prieš pati pirmininkavimą - jau pavasarị Lietuvoje ịvyko pora darbinio lygio susitikimų, kuriuose Lietuva kartu su potencialiomis sąjungininkèmis ES, tokiomis kaip Švedija ir Lenkija, ir Rytų partneriais bandè išsiaiškinti partnerių pageidavimus ir galimą veiklą šioje srityje.

Seminarų metu gimè vadinamasis non-paper - keli puslapiai konkrečiu pasiūlymų, kaip įtraukti partnerius ị BSGP veiklą. Šios idèjos buvo pristatytos pačiame pirmam Lietuvoje vykusiam pirmininkavimo seminare Rytų partnersyčiu tema ${ }^{26}$. Šis renginys pritraukè nemažą dèmesį, o jame dalyvavo ir kelių mažųjų valstybių ministrai. Vèlgi, seminare didžiausią vaidmenį turẻjo mažosios valstybès, ypač iš Vidurio ir Rytų Europos. Seminaro idèjos vèliau pristatytos gynybos politikos direktorių ir gynybos ministrų susitikime, kur jos sulaukè ir didžiųjų šalių, ypač Didžiosios Britanijos ir Prancūzijos, paramos.

Tiesa, ịvykiai Sirijoje nustūmè Rytų partnerystes ị antrą planą (apie tai, kas dèsis vèliau Ukrainoje, tuo metu ne visi galejjo pagalvoti). Tačiau, kai buvo svarstomos Europos Tarybos išvadose, t. y. oficialiame dokumente, kur fiksuojama sutarta ES politika tam tikru klausimu, atsidūrè ir keletas Lietuvos iškeltų idejų. Lietuvos pirmininkavimo metu buvo įsteigtas ir vadinamasis Rytų partnerystės forumas, kuriame ES šalys kartu su partneriais aptaria jiems rūpimus bendradarbiavimo klausimus.

İdomu tai, kad viena iš pirmininkavimo idejų - paramos fondo Rytų partneriams ịsteigimas, buvo igyvendinta tik 2014 metų lapkričio mẻnesị, kai Lietuvos gynybos ministras kartu su Latvijos, Vengrijos ir Didžiosios Britanijos kolegomis pasirašè deklaraciją dẻl fondo darbo pradžios ${ }^{27}$. Tikètina, kad kitos šalys prisijungs vèliau.

Rytų partnerysčių politika yra puikus pavyzdys, kaip maža, aktyvi ir tu-

\footnotetext{
${ }^{26}$ Seminar “Taking CSDP Partnership Forward: the Case of Eastern Partnership", http://www.eu2013.lt/en/ events/political-meetings/conferencesandseminars/seminar-taking-csdp-partnership-forward-the-caseof-eastern-partnership.

${ }^{27} \mathrm{KAM}$, „Kuriamas fondas ES Rytų partnerių gynybai stiprinti“, http://www.delfi.lt/news/daily/lithuania/ kuriamas-fondas-es-rytu-partneriu-gynybai-stiprinti.d?id $=66424700$.
} 
rinti idèjų ES šalis, pasinaudojusi puikia proga, t. y. pirmininkavimu, gali suformuluoti vienminčių koaliciją ir pasiekti savo tikslus. Prie sèkmès prisidejjo ir tai, kad BSGP srityje nè viena didelè šalis neturẻjo esminių problemų skatindama dialogą su Rytų partnerèmis, todèl niekas nekliudẻ Lietuvai igyvendinti savo tikslus. EĮVT šiuo atveju vaidino svarbų, bet ne pagrindinị vaidmenį.

\subsection{Energetinis saugumas}

Energetinis saugumas buvo antras svarbus Lietuvos pirmininkavimo prioritetas. Lietuvos ambicijos BSGP srityje buvo mažesnès kadangi energetinis saugumas iki šiol net nebuvo diskutuojamas BSGP formatu, Lietuva sieke pristatyti problematiką kitoms ES narèms, išaiškinti jos svarbą ir apibrèžti ateities gaires. Veikimo metodas buvo panašus kaip ir su Rytų partnerystemis - seminarai, diskusijos darbinėse grupėse ir aukštesnio lygio susitikimuose. Tiesa, taktika skyrèsi - jeigu Rytų partnerysčių klausimai buvo keliami ị kiek auštesni lygi, tai energetinio saugumo BSGP svarstomi praktiniu-techniniu lygiu. Šiuo tikslu pasitelktas ir NATO energetinio saugumo kompetencijos centras, kurio indèlis turejo skatinti NATO ir ES dialogą. Rezultatas - BSGP atsirado maža energetinio saugumo dimensija, tačiau didžioji darbo dalis persikèlè ị Europos gynybos agentūrą, kuri turètų vykdyti praktinius projektus šioje srityje.

\subsection{Europos Sajungos kovinès grupės}

Pagrindinè problema, kurią matė Lietuva, kaip ir kitos ES valstybės, buvo paprastas - ES kovinès grupés egzistuoja jau dešimt metų, tačiau realiai dar nebuvo panaudotos. Šiuo požiūriu nebuvo skirtumo tarp didelių ir mažu ES valstybių, visas vienijo tas pats rūpestis. Tokioje aplinkoje veikti pirmininkaujančiai valstybei buvo lengviau - reikejo tęsti pradètus darbus, o diskusijų ašimi tapo Lietuvos ir Didžiosios Britanijos bendrai organizuotas seminaras Londone kovinių grupių tema.

Reikia pripažinti, kad nepaisant ịvairiausių pasiūlymų ir vèliau priimtų sprendimų dèl ES kovinių grupių dislokavimo galimybių, iki 2014 m. pabaigos nei viena ES kovinè grupè niekur neišvažiavo, nors tokių galimybių buvo.

Diskusija dèl ES kovinių grupių puikiai iliustruoja, kad prireikus panaudoti bendriems reikalams nacionalinèms valstybėms priklausančius resursus pirmininkaujanti šalis ir EIVT neturi jokių galių primesti šalims sprendimų, o bendri veiksmai susikirtus nacionaliniams interesams yra sunkiai tikètini. 


\subsection{NATO ir ES bendradarbiavimas}

Tai yra nuolat aptariama Europos valstybių tema. Nors neformalus dialogas tarp NATO štabų ir ES institucijų vyksta puikiai, tačiau formalūs santykiai jau seniai yra tapę Kipro ir Turkijos konflikto ịkaitais. Šioje situacijoje pirmininkaujančios šalies vaidmuo nebuvo didelis, o Lietuva jokio proveržio šioje srityje negalejo padaryti.

\subsection{Europos saugumo strategija}

Strategija buvo priimta $2004 \mathrm{~m}$. Pirmasis jos sakinys iškilmingai skelbia „Europa dar niekada nebuvo tokia turtinga ir taiki, kaip dabar“. Toks teiginys buvo teisingas prieš dešimtmetị, tačiau Lietuvos pirmininkavimo laikotarpiu jis atrodè labai keistai. Karas prieš Gruziją, kibernetinès atakos ir ekonominè krizè aiškiai parodè, kad Europa turi persvarstyti savo saugumo prioritetus. Lietuva savo pirmininkavimo laikotarpiu kèlẻ ši klausimą, ją rẻmè ir keletas mažujų šalių, tokių kaip Švedija. Deja, Europos institucijos ir dauguma didžiųjų valstybių nenorejo veltis ị ilgus debatus dèl šio dokumento. Prireikè karo Artimuosiuose Rytuose ir Rusijos agresijos Ukrainoje, kad jau tik 2014 metu pabaigoje dauguma lyderių pripažintų poreikị persvarstyti Europos saugumo strategiją.

Šie keli pavyzdžiai puikiai parodè mažos valstybès, atsidūrusios svarbioje pozicijoje, galimybes ir apribojimus. Maža šalis turi laisvę ir galimybes ittraukti jai svarbius klausimus ị ES darbotvarkę. Itin lengva tai padaryti, kai klausimas potencialiai nepažeidžia nei vienos šalies gyvybinių interesų. Energetinis saugumas BSGP nebuvo svarbus daugeliui šalių, Lietuva neturejo daug sąungininkų, tačiau neturëjo ir didelių priešininkų. Šis klausimas tiesiog natūraliai įsiliejo i̇ praktinę darbotvarkę. Tačiau politiškai jautriu NATO ir ES santykių klausimu pasistūmèti buvo neįmanoma, nebent Lietuva būtų sugalvojusi, kaip praktiškai išspręsti Kipro padalijimo klausimą. Dar sunkiau, kai visos didžiosios šalys sutartinai nepritaria keliamai problemai, kaip tai atsitiko su Europos saugumo strategija. Neatsitiktinai, didžiausi ir labiausi matomi Lietuvos pasiekimai pirmininkavimo metu buvo Rytų partnerysčių srityje. Tai atspindejo bendrą tendenciją ir asocijos sutarčių pasirašymą (ratifikavimą) per pastaruosius metus. 


\section{Išvados}

Kol tarptautinès sistemos pagrindu bus nacionalinès valstybès, Lietuva, kaip ir kitos mažos šalys, ieškos ir ras būdų ginti savo nacionalinius interesus ir laviruoti tarp didžiųjų savo kaimynių. Narystė aljansuose ir tarptautinėse organizacijose yra vienas iš būdų mažoms šalims daryti ịtaką ir pakreipti sau naudinga linkme tarptautinę politiką.

Valstybių dydis ir galia yra svarbu, bet jų itaka NATO ir ES priklauso nuo daugelio veiksnių. Aktyvi, žinanti, ko nori, skirianti didelị dèmesị savo saugumui, turinti gerai paruoštą personalą valstybė visada bus gerbiama, o jos nuomonés klausoma. Savo idejoms skleisti galima pasirinkti didelị priemonių spektrą - pradedant nuo idejos iškèlimo ir baigiant jos igyvendinimu pasinaudojant įvairiais instituciniais mechanizmais. Pasyvi, neišsiugdžiusiu gerų derybininkų ir mažai kuo besidominti šalis bus didžiosios politikos paraštėe.

Straipsnyje aiškiai išdèstyta, kad valstybès įtaka negali būti mechaniškai prilyginta teritorijos, ekonomikos ar karių skaičiaus sumai. Kiti parametrai (dalyvavimas tarptautinèse operacijose ir iniciatyvose, derybiniai sugebejimai, kvalifikuotas personalas) gali neproporcingai stipriai padidinti mažos valstybès sugebejjimą daryti ịtaką sprendimams. Mažoms šalims yra palankūs ir kai kurie struktūriniai veiksniai, ypač konsensuso principo taikymas NATO ir ES.

Straipsnyje taip pat išvardyti ir mažas valstybes ribojantys veiksniai. Joms lengva veikti, kai jų veiksmai neliečia esminių didžiųjų šalių interesų, tačiau kai nuomonès išsiskiria, mažujų valstybiu pasiekimai kuklesni. Lietuvos pirmininkavimas ES Tarybai yra puikus to pavyzdys - nepavyko daug pasiekti sprendžiant NATO ir ES, Europos saugumo strategijos ar netgi ES kovinių grupių klausimus.

Mažoji valstybe turi pati apsispręsti, tik nuo jos pačios veiklumo priklausys, kiek ir kuriose srityse jos klausys didžiosios šalys. NATO ir ES mažajai valstybei reikia daug ir sunkiai dirbti, kad igauti ir išlaikyti pasitikejjimą ir autoritetą.

2015 m. balandis 